\title{
Human Capital, Income and Job Opportunities in Indonesia
}

M.Irji'Sa'Adi , Sri Harnani

(STIE Jaya Negara Tamansiswa Malang)

\begin{abstract}
This study used interviews with 150 online informal workers in Jakarta. $80 \%$ of the respondents we interviewed were high school graduates and $20 \%$ did not have a high school diploma. Based on the results of interviews, $70 \%$ of respondents who had high school certificates had worked in the formal sector and chose to work in the informal sector and respondents who did not have high school certificates had never worked in the formal sector. To anticipate the interview results, we collected secondary data from world banks and the Indonesian Central Bureau of Statistics regarding data on unemployment in Indonesia, high school graduation and high school labor demand. Then we process all data in the form of an employment opportunity index which is calculated based on the supply and demand for labor where the supply of labor is the number of unemployed and graduated high school and the demand for labor in the demand for labor is high. school level. The income index is obtained from interviews with 150 informal workers by taking into account income while working in the formal sector, income in the informal sector and investment in education in the form of education from primary to final education. The human capital index is obtained from the difference in income and forecasting the difference in income of respondents who have a high school diploma and those who do not have a high school diploma. We use average data or all the data obtained is averaged based on a group of variables determined based on literature review and background and time series, then regression is carried out using the moving average autoregression method. We find that human capital and job opportunities have positive relationship with income.
\end{abstract}

Keywords : Human Capital, Income, Job Opportunities

\section{Background}

Generally, in developing countries such as Indonesia, there are very many informal workers. Informal workers are very vulnerable to microeconomic shocks such as loss of work or lack of social protection. Informal workers generally work in the informal business sector such as micro-level businesses or in the household sector (Cornia,2020). Generally, informal workers do not have a sufficient degree of education to be able to work in the formal sector (Bradley \& Green,2019).However, based on the results of interviews with 150 informal workers online in Jakarta $80 \%$ of the respondents we interviewed were high school graduates and $20 \%$ did not have a high school diploma. Based on the results of the interview $70 \%$ of the respondents who have a high school diploma have worked in the formal sector and choose to work in the informal sector and respondents who do not have a high school diploma have never worked in the formal sector. To anticipate the results of the interviews, we collected secondary data from the world bank and the Indonesian Central Bureau of Statistics regarding data on unemployment in Indonesia, high school graduation and labour demand for senior high school levels. Then we process all data in the form of a job opportunity index which is calculated 
by labour supply and demand where labour supply is the sum of unemployment and high school graduation, and labour demand in labour demand for high school level. Income index obtained from interviews with 150 informal workers by taking into account income while working in the formal sector, income in the informal sector and investment in education in the form of schooling from primary level to the last level of education taken. The human capital index is obtained from the difference in income and forecasting the difference in income from respondents who have a high school diploma and those who do not have a high school diploma. Based on the results of interviews and literature studies, we conclude a provisional conclusion or hypothesis that income levels are influenced by human capital and job opportunities.

\section{Literature Review}

Wages increase in line with rising prices in developing countries such as Indonesia. Every time there is an increase in the minimum wage, the price increases in general. This has the effect of rising shadow wages. Where the increase in labour wages does not improve the welfare of workers. So that income must take into account the increase in real prices when there is an increase in wages (Kozul-Wright \& Rayment,2007). When a worker wants to increase his income, he has to work harder (Etherington,2020). However, sometimes the opportunity to work harder does not exist so that the impact on income is similar over time and when there is an increase in wages it cannot compensate for the increase in prices in general (Lavoie \& Stockhammer,2013). To increase income, a worker must have the ability to increase his human capital so that he can do something that can improve his welfare(Bucci,et al.,2019.).(Job opportunities ,of course ,have certain skill criteria that must be met. Human capital investment is one way to increase job opportunities to increase one's income (Widarni \& Bawono,2020).

\section{Research Method}

Data collection in this study used interviews with 150 online informal workers in Jakarta. $80 \%$ of the respondents we interviewed were high school graduates and $20 \%$ did not have a high school diploma. Based on the results of interviews, $70 \%$ of respondents who had a high school diploma had worked in the formal sector and chose to work in the informal sector and respondents who did not have a high school diploma had never worked in the formal sector. To anticipate the results of the interviews, we collected secondary data from world banks and the Indonesian Central Bureau of Statistics regarding data on unemployment in Indonesia, high school graduation and labour demand for senior high school levels. Then we process all data in the form of an employment opportunity index which is calculated based on the supply and demand for labour where the supply of labour is the sum of unemployment and high school graduation and demand for labour in the demand for labour for the high school level. The income index is obtained from interviews with 150 informal workers by taking into account income while working in the formal sector, income in the informal sector and investment in education in the form of education from primary to final education. The human capital index is obtained from the difference in income and forecasting the difference in income of respondents who have a high school diploma and those who do not have a high school diploma. We use average data or all the data obtained is averaged based on a group of variables determined based on literature and background reviews and time series, then the regression is carried out using the moving average autoregression method with the following equation: 
$\mathrm{I}_{\mathrm{t}}=\mathrm{C}_{\mathrm{t}}+\beta_{1} \mathrm{JO}_{\mathrm{t} 1}+\beta_{2} \mathrm{HC}_{2}+\mathrm{e}_{\mathrm{t}}$

Where,

$\mathrm{I}=$ Income

$\mathrm{JO}=$ Job Opportunities

$\mathrm{HC}=$ Human Capital

$\mathrm{e}=$ Term Error

\section{Result and Discussion}

The estimation results are as follows:

$\mathrm{I}=-0.0795628049075+0.410577219098 * \mathrm{HC}+0.649492205423 * \mathrm{JO}$

From the estimation results, Human Capital and job opportunities have a positive effect on income. Where every $1 \%$ increase in income is followed by an increase in Human Capital of $0.41 \%$ and job opportunities of $0.65 \%$ which are briefly described in Table 1 illustrates the estimation results as follows:

Table 1. Estimation Results

\begin{tabular}{|l|l|l|l|l|}
\hline Variable & Coefficient & Std. Error & t-Statistic & Prob. \\
\hline C & -0.079563 & 0.107221 & -0.742047 & 0.4682 \\
\hline HC & 0.410577 & 0.20889 & 1.965522 & 0.0659 \\
\hline JO & 0.649492 & 0.197846 & 3.282813 & 0.0044 \\
\hline R-squared & 0.79747 & \multicolumn{2}{|l|}{ Mean dependent var } & 0.74525 \\
\hline Adjusted R-squared & 0.773643 & S.D. dependent var & 0.147902 \\
\hline S.E. of regression & 0.070367 & Akaike info criterion & -2.332696 \\
\hline Sum squared resid & 0.084176 & Schwarz criterion & -2.183336 \\
\hline Log likelihood & 26.32696 & Hannan-Quinn criter. & -2.303539 \\
\hline F-statistic & 33.46902 & Durbin-Watson stat & 2.126381 \\
\hline Prob(F-statistic) & 0.000001 & \\
\hline
\end{tabular}

Based on the estimation results described in Table 1. Income reflects Human Capital and job opportunities. The following is the forecast for the employee income index in Indonesia from 2000 to 2019 in Figure 1 as follows:

Figure 1. The results of forecasting the employee income index in Indonesia
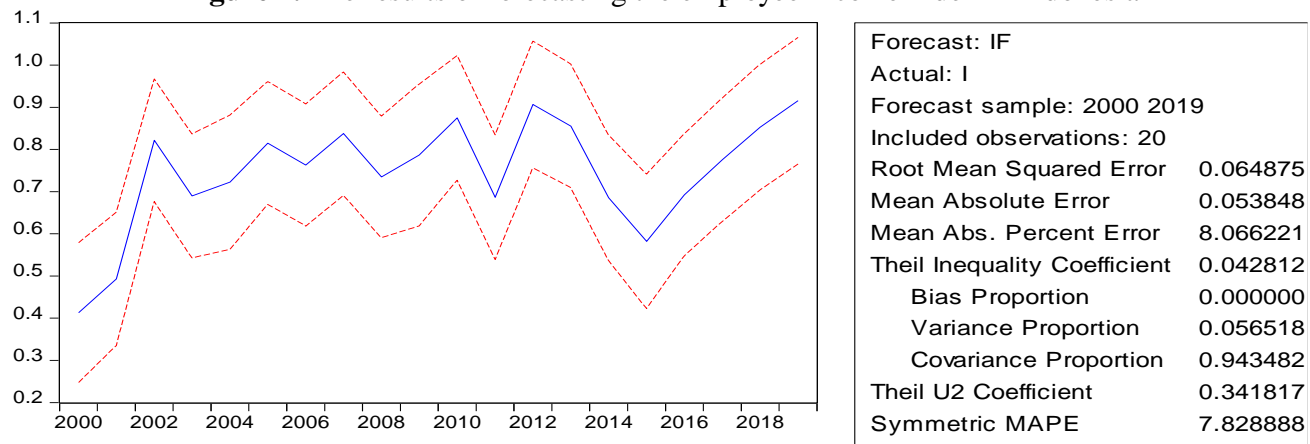

Source: Author's computation 
Based on the forecast in Figure 1, the development of employee income in Indonesia tends to fluctuate according to economic conditions in Indonesia. This proves that employee income or human income is influenced by various factors and in the results of this study human capital and job opportunities obtained contribute to the amount of a person's or human income.

\section{Conclusion}

Human income is the result of work that can be sold or generate income where it is influenced by human capital owned and the opportunity to work or the opportunity to sell their skills for income.

\section{Reference :}

Bradley,S.,Green,C.(2019).The Economics of Education: A Comprehensive Overview. Amsterdam : Elsevier

Bucci,A., Prettner,K. ,Prskawetz,A.(2019).Human Capital and Economic Growth: The Impact of Health, Education and Demographic Change. Cham : Springer

Cornia,G.A.(2020).The Macroeconomics of Developing Countries: An Intermediate Textbook. Oxford : Oxford University

Etherington,D.(2020).Austerity, Welfare and Work: Exploring Politics, Geographies and Inequalities. Bristol : Policy Press

Kozul-Wright,R., Rayment,P.(2007).The Resistible Rise of Market Fundamentalism: Rethinking Development Policy in an Unbalanced World. Michigan : Bloomsbury Academic

Lavoie,M., Stockhammer,E.(2013).Wage-Led Growth: An Equitable Strategy for Economic Recovery. Cham: Springer

Widarni,E.L., Bawono,S.(2020).Human Capital Investment For Better Business Performance. Singapore: Triplenine Communication 